\title{
CHANGES OF STRATEGIC PRICING POLICY OF LOGISTICS SERVICE PROVIDERS IN FINANCIAL MACROECONOMIC INSTABILITY
}

(iD) Libor Simek ${ }^{1+}$
(iD) Vaclav Cempirek ${ }^{2}$
(iD) Andrej David ${ }^{3}$
(iD) Andrea
Galierikova $^{4}$

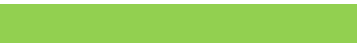

Article History

Received: 7 October 2021 Revised: 10 November 2021 Accepted: 3 December 2021 Published: 24 December 2021

\section{Keywords}

Corporate finances Strategic pricing policy Alternative firm theory Financial crisis

Macroeconomic instability Logistics providers.

JEL Classification: D40, D21, H12, M31, G39, F62.

\author{
${ }^{'}$ Doctoral student, Faculty of Economics and Administration, Studentska, \\ Pardubice, Czech Republic. \\ 'Email:libor.simek1@seznam.cz Tel:+420606491669 \\ ${ }^{2}$ Professor of College of Logistics, Palackeho, Prerov, Czech Republic. \\ ${ }^{2}$ Email:vaclav.cempirek@vslg.cz Tel: +420 581259133 \\ ${ }^{3,4}$ Associate Professor of University of Zilina, Univerzitna, Zilina, Slovak \\ Republic. \\ ${ }^{s}$ Email:Andrej.David@fpedas.uniza.sk Tel: +421415133550 \\ "Email:andrea.maternova@fpedas.uniza.sk Tel: +421 415133552
}

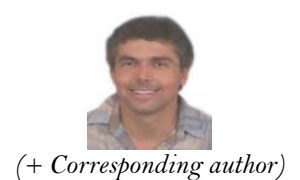

(+ Corresponding author)

\begin{abstract}
This paper aims to examine the influence of macroeconomic instability on the microeconomic environment, especially on financial strategy after the application of strategic pricing policy by providers of logistics services and make recommendations for providers who use pricing as a marketing tool. Special attention is paid to enhancing their competitive position in times of economic crisis. The research is based on an analysis of the situation during the 2008-2009 economic crisis. It is hypothesized that the number of providers who applied a strategic pricing policy after its culmination in 2010 was higher than in 2008 (shortly before the onset of the crisis). The conclusions derived are then transferred to the period of the 2020 coronavirus economic recession under the assumption of the same analogical characteristics of both periods. The paper does not speculate - its purpose is to present a thorough and complex analysis of the situation by employing a wide range of statistical instruments, thereby attaining results of a very high level of statistical reliability. The study has the potential to be a valuable contribution to the literature in its respective field, especially during global anti-Covid measures, which makes the theme of strengthening competitive positions of logistics service providers very topical.
\end{abstract}

Contribution/Originality: This study is one of very few studies which have investigated the influence of macroeconomic instability, i.e., economic crisis, on pricing strategy of logistics service providers. It provides them with practical recommendations for formulating their pricing policies in order to survive in an economically turbulent environment of intense competition.

\section{INTRODUCTION}

An organization which coordinates the processes concerning the production and distribution of goods (Klaas, McClendon, \& Gainey, 1999) continues operating on the condition that the administrative costs associated with the use of internal resources are lower than the costs that the firm would incur with the use of external or third party resources (Baumol, Cyert, \& March, 1964). Another reason for the establishment of a logistics firm is to realize economies of scale (Coase, 2012). Cournot's marginal theory of starting a firm is one of the first scientific concepts justifying the existence of a firm. Joan Robinson came to the conclusion that the real-world demand for a company's product or service is not stable but declines, and it defines the conditions for the existence of competition. This gave 
rise to the neoclassical theory of the firm, which represents a major stream in the subject area of microeconomic science. However, over time as knowledge about the reality of firms has deepened, alternative theories of the firm have emerged, with managerial and behavioral theories having the most important positions.

Although the starting points of the abovementioned approaches to the concept of the firm theory differ (Vijay, 2000), economists agree that the primary reason for the firm's existence is to generate a profit, no matter whether it is as a reward for its special qualities and skills as a business entity, as a reward for the risk it takes, as a reward for the entrepreneur's ability to reduce or eliminate risk, or any benefit ensuing from the process of innovation and technological progress in general. It is also clear that, despite the different concepts of profit, profit realizes several functions in the company, primarily as a source of the accumulation of funds, which is the main criterion for all decision-making processes and the fundamental motive for continuing its business activities. At the same time, the alternative theories of the firm deviate from the concept of the neoclassical theory of the firm, which assumes the maximization of profit (Conner \& Prahalad, 1996) and emphasizes that the goal of the firm is to achieve the maximum level of profit. Instead, the alternative theories of the firm state that the aim of the firm is to achieve a certain level of profit, which is satisfactory for all stakeholders of the firm.

The above concepts also apply to the corporate providers of logistics, where, owing to the global coronavirus economic recession of 2020 (Ahsan \& Larry, 1988) and the related necessity to introduce a wide range of measures in order to prevent the disease spreading, the problems of economic adaption and economic survival become the most urgent issues.

\section{THEORETICAL FUNDAMENTS}

\subsection{Post-Keynesian Models of Limit Pricing}

Among the alternative theories of the firm, institutional and post-Keynesian models have a dominant position (Pause et al., 2020). This is because these are mainly devoted to oligopolistic corporate structures, i.e., large companies, which are a characteristic feature of modern economies. From a theoretical point of view, this paper focuses on post-Keynesian models, which are characterized by the fact that they strongly reject the neoclassical assumption of profit maximization by firms and emphasize the fact that the behavior of the firm cannot be predicted with certainty (assumption of constant uncertainty). They use exact mathematical models to make their statements (Coase, 2012). These theories combine both microeconomic and macroeconomic aspects, emphasizing the role that institutions play in the economy. In their analyses, they also emphasize the production process, less so the behavior of the company in the market when selling its products (Naidoo, 2010). Among the post-Keynesian models are Kalecký's model of mark-up pricing, Eichner's model of pricing with the required rate of return, and Labini's model of limit pricing, all of which have an important place.

\subsection{Kaleckýs Model of Mark-Up Pricing}

The model assumes that the firm determines price based on mark-up pricing instead of attempting to reach maximum profit, which means adding a surcharge to the variable costs it incurs in connection with production (Harrison \& Wicks, 2013). This surcharge then covers both fixed costs and the firm's profit.

The model is based on the following assumptions:

- If the variable costs are constant, the supply of the firm is perfectly elastic; this means that an increase in demand only leads to an increase in the firm's supply of products (and, therefore, also to an increase in price).

- An increase in costs results in a price increase; this means that the firm does not reduce its mark-up (surcharge to the price), but, on the contrary, increases the price.

- The price remains constant even if the firm's costs are reduced (for example, due to technological progress); this means that the firm does not reduce its surcharge, but instead increases it, keeping the price constant, enhancing its profits, and gaining the opportunity to increase wages for its employees. 
When determining the level of the surcharge, the firm makes a decision on the basis of the actual market situation, especially with regard to the position of its competitors and taking into account the degree of monopolization of the given market segment (Kjeldgaard \& Askegaard, 2006). It is obvious that, with lower market monopolization, the importance of this criterion for determining the surcharge increases. In this model, pricing policy becomes an important factor in the competitive struggle, which, under certain circumstances, for example, in time of economic fluctuations, turbulence, or crisis, may even decide the firm's survival.

\subsection{Eichner's Model of Pricing with the Required Rate of Return}

Eichner's model is based on the assumption that the firm formulates its pricing policy to achieve the required return on its fixed capital from its normal production output (Eichner, 1987). The price surcharge is determined so that the price covers the firm's fixed costs and the need to maintain a reserve fund. An important conclusion that ensues from this model is that the firm has only one source of financing its investments if the owners are unwilling to accept a lower level of dividends paid out, which is possible if the mark-up (surcharge to the price) is increased. It must be pointed out, however, that this brings about a considerable risk of worsening the firm's position among the competition, thus jeopardizing its existence. For this reason, a pricing strategy based on this model cannot be used to improve competitive position, which can have fatal consequences for the firm, especially in times of economic instability. Therefore, in the context of this paper, which deals with the application of strategic pricing policy with a focus on enhancing competitive position in macroeconomic instability, this model is not relevant.

\subsection{Labini's Model of Limit Pricing}

The model assumes that the firm tries to determine a limit price (Amin \& Thrift, 1992), which would:

- Discourage potential competitors from entering the given sector.

- Force the existing competitors to leave the sector (eliminate them economically).

- The model stipulates three pricing policies (Järvinen \& Taiminen, 2016):

- Price with a minimum profit margin - this price ensures the lowest rate of return that is still acceptable for the firm.

- Price for market protection - this price prevents potential competitors from entering the given market sector; this price is lower than the above price with a minimum profit margin.

- $\quad$ Price for market exit of competitors - this price forces the existing competitors to leave the market.

- Regarding the policy of price determination, i.e., the price for market exit of competitors, there are two tactics, namely the tactics for a short and a long period.

- Short period - the firm sets the price for the market exit of competitors so that it is lower than the variable costs. This tactic is based on the simple assumption that, if the price does not cover the variable costs, then discontinuation of production and market exit of the firm will result in a smaller loss than if production continued.

- Long period - if the firm intends to liquidate its competitors economically, the determined price should not cover the sum of the variable and fixed costs. This tactic is again based on the simple assumption that a company must discontinue its presence in the market if, in the long run, the price does not cover the sum of the variable costs and the price surcharge (which serves to cover the company's fixed costs).

This model is based on the supposition that, along with the increasing size of the company, the limit price decreases, which applies to both the price with a minimum profit margin and the price for market exit of competitors. This is because the larger the company, the larger the volume of its production and, therefore, the lower its variable costs (Kjeldgaard \& Askegaard, 2006). This leads to the fact that, at given limit prices, a large company will have a much better chance of surviving economically than a small company, whose variable costs are relatively high. The model further assumes that the firm is limited in its production by the factor of technology 
(Harrison \& Wicks, 2013), which, in practice, means that the firm is not able to increase production continuously but in quantitative jumps, so there may be certain production gaps, and this throws doubt on another assumption of the neoclassical theory of the firm.

From the viewpoint of the research presented, Labini's model of limit pricing is the most interesting because it represents an integration of strategic marketing (strategic pricing) into the theory of the firm itself. It assumes that the firm has chosen its pricing policy as a strategic tool to beat its competitors, which is crucial in times of intensified competition.

\section{SUBJECT OF RESEARCH}

The purpose of this research is to formulate practical guidelines for the providers of logistics services to enable them to apply strategic pricing policy as a marketing tool. Special attention is devoted to strengthening providers' competitive positions in order to provide them with an advantage over their competitors, which can significantly enhance their chances of economic survival in times of macroeconomic instability. The research is empirically based and is built on the analysis of the situation during the economic crisis of 2008-2009. First, an analysis of the influence of the 2008-2009 macroeconomic instability on the pricing policy of firms is performed and conclusions derived. Second, these conclusions are applied to the period of the 2020 economic recession under the presumption that the analogical characteristics of both periods of macroeconomic instability are the same. This recession, although of a different origin than the 2008-2009 crisis, manifests the same symptoms (i.e., features with economic impact) of a classic financial crisis, such as the 2008-2009 crisis, which satisfies the abovementioned presumption of the presence of the same analogical characteristics in both periods (Gourinchas, 2020).

The main merit of the analysis of the 2008-2009 crisis lies in determining its eventual influence on the strategic pricing policy of providers of logistics services. The analysis compares the situation in this field in the year shortly before the onset of the crisis (2008) and shortly after its culmination (2010). Formulated in more concrete terms, the analysis compares two relative counts of the providers applying the strategic pricing policy (based on the post-Keynesian concept as defined below) across the 2008-2009 crisis with the aim of detecting a statistically significant difference, which could indicate that the crisis, and macroeconomic instability in general, could have an influence in this respect.

For this purpose, it is necessary to define the term "strategic pricing policy". This notion is based on the presumption that any economic instability (crisis) brings about intensified market competition and puts increased pressure on the optimization of resource allocation. This means that the above specified types of strategic pricing policy - if they are to improve the competitive position of the firm - must be formulated in such a manner so that they lead to a price reduction. Based on this requirement, we can, for the purpose of the analysis, propose a precise strategic pricing policy so that it leads to a price reduction. Thus, under the term "strategic pricing policy", we can explain the post-Keynesian models described below.

\subsection{Labini's Model of Limit Pricing}

As we explained in the theoretical part, this model provides the firm with the greatest opportunity for realization a strategic pricing policy. In order to discourage potential competitors from entering the given market segment, or to force existing competitors to leave it, the model offers the firm, as a means of competition struggle, three policies, i.e., three methods of strategic pricing formulation. These are as follows:

1. Determine the price with the minimum profit margin (the minimum price that is still acceptable for the firm).

2. Determine the market protection price (which is intended to discourage potential competitors from entering the market segment and is lower than the price with a minimum margin).

3. Determine the price for the market exit of competitors. 
As stated above, there are two types of pricing policy aimed to force competitors to exit the market - shortterm tactics vs. long-term tactics. The former tactics mean that the firm can set the price lower than the variable costs, thus forcing its competitors to leave the market in a short period. On the contrary, the latter tactics imply that the firm sets the price so low that it does not cover either variable or fixed costs, which means that it does not cover the mark-up (price surcharge). Thus, it is clear that only the long-term variant of strategic pricing policy is an effective tool to force tenacious competitors to exit the market, especially if the competitors are so-called "big" companies. This is because the ability to withstand the market pressure of the reduced price as a result of strategic pricing policy increases with the size of such an economically "attacked" company compared with smaller companies.

\subsection{Kaleckýs Model of Mark-up Pricing}

In this model, the possibilities of applying a strategic pricing policy are considerably limited because it assumes that as the firm's costs increase the price increases too, and thus assumes that the firm does not reduce its price surcharge (mark-up). For this reason, in the case of this model, the only way to formulate a strategic pricing policy to improve competitive position involves enhancing (promoting) the importance (weight) of the two criteria below that are used in the decision-making process of the mark-up (price surcharge) determination:

- Position of the competitors (the stronger the position, the more pressure on low mark-up).

- Degree of market monopolization of the given segment (industry).

It can be assumed that the more intense the competition, the greater the weight of this criterion in the decisionmaking process, and thus the greater the pressure for the company to set the price surcharge at a very low, or at least a reasonable, level.

\subsection{Eichner's Pricing Model With the Required Rate of Return}

This model, as a tool of strategic pricing policy, cannot and will not be applied because, as stated in the theoretical section, when increasing costs, the firm does not reduce its price surcharge, which means that the price will also increase. This is because an increase of the surcharge represents the only source of investment financing (unless the owners of the firm agree to having reduced dividend yields).

For the purpose of the verification of the influence of macroeconomic instability on strategic pricing policy applied by the logistics service providers, a hypothesis was formulated assuming that the degree of application of pricing strategic policy by providers based in the Czech Republic changed statistically after the economic crisis of 2008-2009. The exact formulation is as follows:

$H_{0:}$ "The proportion of logistics service providers applying the strategic pricing policy in 2010 is higher than that in 2008."

This hypothesis will be verified in a statistically exact manner, using a number of statistical tests and procedures to compare statistical samples in accordance with the principle of statistical multi-instrumentality, as specified below.

\section{METHODS}

\subsection{Collection of Data}

We used Albertina's company database ("company monitor") to select the logistics providers (potential respondents). The data was collected in the form of telephone surveys because this method was expected to yield a higher response rate with more reliable responses than with a classic data collection method using questionnaires (Cosgrove, Pettis, \& Mullett, 1979). The selection of potential respondents - providers of logistics services - was carried out through an internal search tool, which was set to the following specific selection criteria:

- $\quad$ Provide logistics services for corporate customers. 
- Carry out their activities for the purpose of generating a profit (therefore budgetary and contributory organizations were excluded).

- Have 300 or less employees.

- Have the status of a legal entity (natural persons have been eliminated from the selection).

- Have their registered office in the Czech Republic (regardless of eventual ownership connected to any foreign entity).

Based on the above criteria, 126 logistics service providers were contacted with a request for information through telephone inquiries. This number is sufficient for the formulated hypothesis to be verified, not only by exact statistical tests, but also asymptotic tests.

\subsection{Analysis of Data}

In accordance with the principle of statistical multi-instrumentality, the hypothesis was verified using a set of statistical tools. As the situation compares two years (2008 vs. 2010), the respondents (providers) had a choice of two applications of the strategic pricing policy (No vs. Yes), and both mutually compared provider samples did not contain the same entities (the samples were not identical, i.e., they were independent/unpaired/uncorrelated), so we compared two independent binomial proportions.

The internal structure of the providers was ignored, which means providers were not divided into groups, and the analysis was carried out based on a chosen characteristic feature of the sampled companies.

\section{RESULTS OBTAINED}

\subsection{Respondent Information Yield}

For 2008,95 respondents $(75.40 \%$ of the total number of 126 contacted companies) provided the required data. The number of respondents who provided data for 2010 rose to 109 (86.51\%) (see Table 1 and Figure 1).

Table-1. Respondent information yield [respondents vs. companies contacted count].

\begin{tabular}{|c|c|c|c|c|c|c|}
\hline \multirow{2}{*}{$\begin{array}{c}\text { Analysis Time } \\
\text { Span (Number } \\
\text { of Years } \\
\text { Compared) }\end{array}$} & \multirow{2}{*}{$\begin{array}{c}\text { Inter- } \\
\text { Sample } \\
\text { Correlation }\end{array}$} & \multirow{2}{*}{$\begin{array}{l}\text { Number of } \\
\text { Application } \\
\text { Alternatives }\end{array}$} & \multirow{2}{*}{$\begin{array}{c}\text { Sample } \\
\text { Homogeneity }\end{array}$} & \multirow[t]{2}{*}{ Year } & \multicolumn{2}{|c|}{ Respondent (Company) Count } \\
\hline & & & & & Absolute & $\begin{array}{c}\text { \% of Total Providers } \\
\text { Contacted }\end{array}$ \\
\hline \multirow[t]{2}{*}{2 years } & \multirow{2}{*}{$\begin{array}{l}\text { Independent } \\
\text { Samples }\end{array}$} & \multirow[t]{2}{*}{2} & \multirow{2}{*}{$\begin{array}{c}\text { Homogeneous } \\
\text { (No stratification) }\end{array}$} & 2008 & 95 & 75.40 \\
\hline & & & & 2010 & 109 & 86.51 \\
\hline
\end{tabular}

\subsection{Application of Strategic Pricing Policy}

\subsubsection{Formulation of Hypothesis}

The data obtained from the respondents (logistics service providers) is shown in Table 2 and Figure 1. In 2008, the strategic pricing policy was applied by 33 providers $\left(\mathrm{P}_{2008}=34.74 \%\right.$ of the total number of 95 respondents who provided the required data for the given year). In 2010, the number of providers applying the policy increased to 51 $\left(\mathrm{P}_{2010}=46.79 \%\right.$ of the total number of 109 respondents who provided the required data for the given year $)$. This leads us to the hypothesis that the application of the strategic pricing policy has increased on a year-on-year basis (across the period of the 2008-2009 economic crisis). 
Table-2. Strategic pricing policy application [2008 vs. 2010].

\begin{tabular}{c|c|c|c|c}
\hline \multirow{2}{*}{ Year } & \multicolumn{3}{|c}{ Provider Count } \\
\cline { 2 - 5 } & \multicolumn{2}{|c}{ Absolute } & \multicolumn{2}{|c}{ \% of Total Providers Contacted } \\
\cline { 2 - 5 } & No & Yes & No & Yes \\
\hline 2008 & 62 & 33 & 65.26 & 34.74 \\
\hline 2010 & 58 & 51 & 53.21 & 46.79 \\
\hline
\end{tabular}
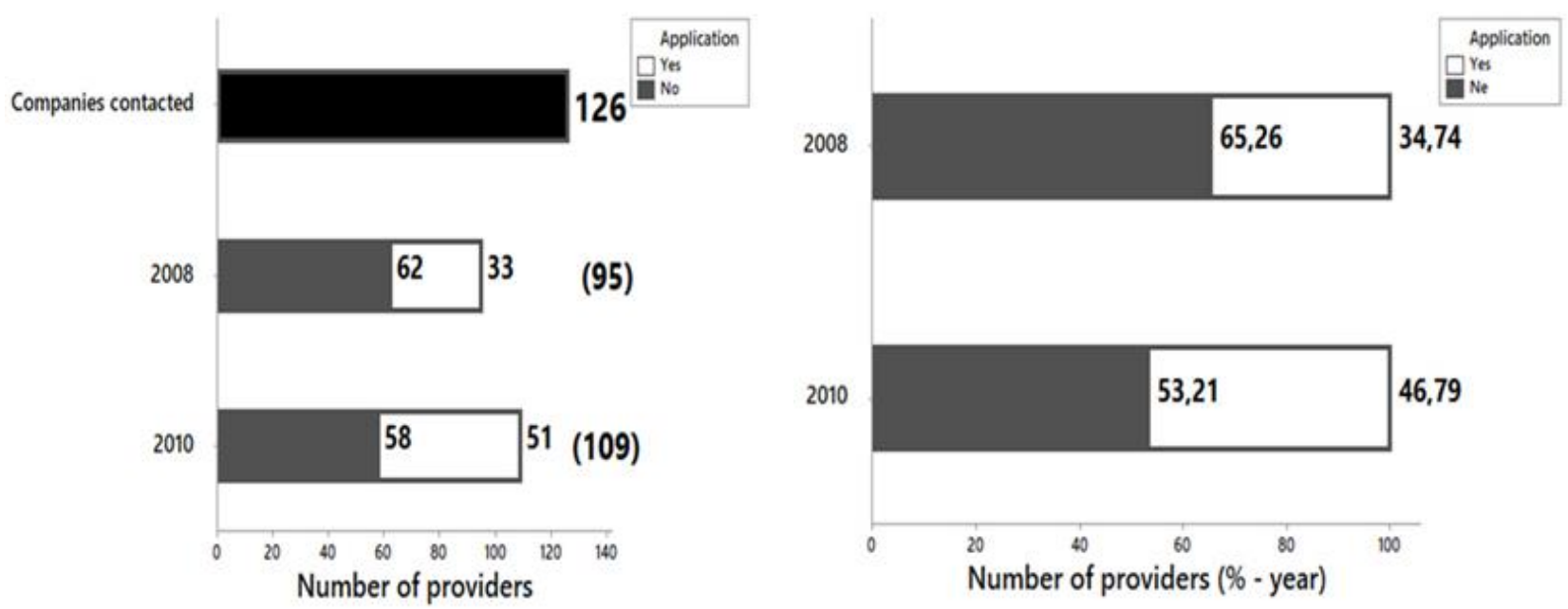

Figure-1. Strategic pricing policy application [2008 vs. 2010].

\subsubsection{Verification of Hypothesis}

In a statistically exact manner, the hypothesis is verified using the statistical procedures and tests as specified below, namely the unpaired tests for $2 \times 2$ table. The verification includes detecting a year-on-year difference (2008 vs. 2010) in application of strategic pricing policy, which, as explained in detail above, means comparing two yearly proportions of strategic pricing policy application. In this respect, the unpaired tests for the $2 \times 2$ table can be performed in three variants, and the tests can be divided into three groups accordingly depending on the aspect from which the difference is examined. From the viewpoint of a statistical analysis, the difference of the proportions can be regarded in three manners, i.e., as:

1. the difference of the proportions $\left(\mathrm{P}_{2010}-\mathrm{P}_{2008}\right)$.

2. the ratio of the proportions $\left(\mathrm{P}_{2010} / \mathrm{P}_{2008}\right)$.

3. the odds ratio of the proportions $\left(\mathrm{O}_{2010} / \mathrm{O}_{2008}\right.$, where $\left.\boldsymbol{O}_{\boldsymbol{Y} \boldsymbol{R}}=\frac{\boldsymbol{P}_{\boldsymbol{Y}}}{\mathbf{1 - P _ { Y K }}}\right)$.

The above three approaches can yield different (i.e., not compatible) test results, potentially also leading to incompatible conclusions. So, this complex approach to testing (principle of statistical multi-instrumentality) was chosen for the sake of high reliability of verification, thereby also attaining high significance of the conclusions derived.

\subsubsection{Analysis Outcome (Unpaired test for the $2 x 2$ table)}

5.2.3.1. Difference of Proportions $\left(P_{2010}-P_{2008}\right)$

5.2.3.1.1. Test

We tested the null hypothesis assuming that the difference of the 2010 application proportion and the 2008 application proportion equals $\mathrm{O}$ versus the alternative hypothesis that assumes the opposite, i.e.:

$$
\mathrm{H}_{0}: \mathrm{P}_{2010}-\mathrm{P}_{2008}=0 \text { vs. } \mathrm{H}_{\mathrm{a}}: \mathrm{P}_{2010}-\mathrm{P}_{2008} \neq 0
$$


All the tests performed and detailed in Table 3 indicate that the observed probability of the null hypothesis being true is in the interval of 0.0803 to 0.1091 . For example, the most commonly frequented Wald $\mathrm{Z}$ test returns the test statistic of 1.745 and an observed probability value (p-value) of 0.0810 . Since the observed probability value is greater than the statistical significance level applied in the test $(\alpha=0.05=5 \%$ ), we cannot reject the null hypothesis $\left(\mathrm{H}_{0}\right)$ and we must state that the difference between the 2010 application proportion and the 2008 application proportion is equal to 0 . This means that the test regarding the proportion difference (obtained by mutually subtracting the proportions, i.e., $\left.\mathrm{P}_{2010}-\mathrm{P}_{2008}\right)$ did not detect any statistically significant difference between application of strategic pricing policy in 2008 versus 2010 (i.e., across the period of the 2008-2009 economic crisis).

Table-3. Unpair test for the 2x2 table - difference of proportions [Basic analysis]

\begin{tabular}{|c|c|c|c|c|c|c|}
\hline \multirow[t]{2}{*}{ TEST } & \multicolumn{2}{|c|}{$\begin{array}{l}\text { Application } \\
\text { proportion }\end{array}$} & \multirow[t]{2}{*}{$\mathbf{P}_{2010}-\mathbf{P}_{2008}$} & \multirow[t]{2}{*}{$\begin{array}{c}\text { Test } \\
\text { statistics }\end{array}$} & \multirow{2}{*}{$\begin{array}{c}\text { Observed } \\
\text { probability (p- } \\
\text { value) }\end{array}$} & \multirow[t]{2}{*}{$\begin{array}{c}\text { Reject } \mathrm{H}_{0} \text { at } \\
\alpha=0.05 ?\end{array}$} \\
\hline & $\mathbf{P}_{2010}$ & $\mathbf{P}_{2008}$ & & & & \\
\hline Wald Z & 0.4679 & 0.3474 & 0.1205 & 1.745 & 0.0810 & No \\
\hline $\begin{array}{l}\text { Wald Z with } \\
\text { Continuity Correction }\end{array}$ & 0.4679 & 0.3474 & 0.1205 & 1.602 & 0.1091 & No \\
\hline Wald Chi-square & 0.4679 & 0.3474 & 0.1205 & 3.044 & 0.0810 & No \\
\hline $\begin{array}{l}\text { Wald Chi-square with } \\
\text { Continuity Correction }\end{array}$ & 0.4679 & 0.3474 & 0.1205 & 2.567 & 0.1091 & No \\
\hline Mantel-Haenszel & 0.4679 & 0.3474 & 0.1205 & 1.740 & 0.0818 & No \\
\hline Likelihood Ratio & 0.4679 & 0.3474 & 0.1205 & 3.059 & 0.0803 & No \\
\hline Fisher's Exact & 0.4679 & 0.3474 & 0.1205 & 0.089 & 0.0887 & $\mathrm{No}$ \\
\hline $\begin{array}{l}\text { Fisher's Conditional } \\
\text { Exact }\end{array}$ & 0.4679 & 0.3474 & 0.1205 & & & \\
\hline $\begin{array}{l}\text { Pearson's Conditional } \\
\text { Exact }\end{array}$ & 0.4679 & 0.3474 & 0.1205 & & & \\
\hline $\begin{array}{l}\text { Likelihood Ratio } \\
\text { Conditional Exact }\end{array}$ & 0.4679 & 0.3474 & 0.1205 & & & \\
\hline Barnard's Exact & 0.4679 & 0.3474 & 0.1205 & & & \\
\hline
\end{tabular}

\subsection{Confidence Intervals}

All the procedures which were carried out are detailed in Table 4 and Figure 2, and indicate that the value of the year-on-year proportion difference $\left(\mathrm{P}_{2010}-\mathrm{P}_{2008}\right)$ equals 0.1205. For example, the most commonly used Wilson score procedure with continuity correction for confidence intervals shows that the proportion difference equals 0.1205 and is in the interval of -0.0216 to 0.2553 with a $95 \%$ probability, i.e., in the interval with the width of 0.2768. This means that, assuming the given statistical significance level $(\alpha=0.05=5 \%)$, the procedure regarding the proportion difference as a difference (obtained by mutually subtracting the proportions, i.e., $\mathrm{P}_{2010}-\mathrm{P}_{2008}$ ) did not detect any statistically significant difference between application of strategic pricing policy in 2008 versus 2010 (i.e., across the period of the 2008-2009 economic crisis), which supports the result obtained using the tests specified in the section above.

\subsubsection{Ratio of Proportions $\left(P_{2010} / P_{2000}\right)$}

\subsection{Test}

We tested the null hypothesis, which assumes that the ratio of the 2010 application proportion and the 2008 application proportion equals 1 versus the alternative hypothesis assuming the opposite, i.e.:

$$
\mathrm{H}_{0}: \mathrm{P}_{2010} / \mathrm{P}_{2008}=1 \text { vs. } \mathrm{H}_{\mathrm{a}}: \mathrm{P}_{2010} / \mathrm{P}_{2008} \neq 1
$$

The most commonly used Wald $Z$ test returned a test statistic of 1.745 and an observed probability value (pvalue) of 0.0810 , as shown in Table 5 . 
Table-4. Unpair test for the 2 x2 table - Difference of proportions - Confidence intervals [Basic analysis].

\begin{tabular}{|c|c|c|c|c|c|c|}
\hline \multirow[t]{2}{*}{ Procedure } & \multicolumn{2}{|c|}{$\begin{array}{l}\text { Application } \\
\text { proportion }\end{array}$} & \multirow[t]{2}{*}{$\mathbf{P}_{2010}-\mathbf{P}_{2008}$} & \multicolumn{3}{|c|}{ Confidence intervals $(\mathbf{9 5 \%})$ for $\mathbf{P}_{2010}-\mathbf{P}_{2008}$} \\
\hline & $\mathbf{P}_{2010}$ & $\mathbf{P}_{2008}$ & & Lower limit & Upper limit & Width \\
\hline Wald Z & 0.4679 & 0.3474 & 0.1205 & -0.0134 & 0.2545 & 0.2679 \\
\hline $\begin{array}{l}\text { Wald } \mathrm{Z} \text { with Continuity } \\
\text { Correction }\end{array}$ & 0.4679 & 0.3474 & 0.1205 & -0.0233 & 0.2643 & 0.2876 \\
\hline Wilson Score & 0.4679 & 0.3474 & 0.1205 & -0.0147 & 0.2488 & 0.2634 \\
\hline $\begin{array}{l}\text { Wilson Score with } \\
\text { Continuity Correction }\end{array}$ & 0.4679 & 0.3474 & 0.1205 & -0.0216 & 0.2553 & 0.2768 \\
\hline Farrington-Manning Score & 0.4679 & 0.3474 & 0.1205 & -0.0149 & 0.2509 & 0.2658 \\
\hline Miettinen-Nurminen Score & 0.4679 & 0.3474 & 0.1205 & -0.0153 & 0.2512 & 0.2664 \\
\hline Gart-Nam Score & 0.4679 & 0.3474 & 0.1205 & -0.0149 & 0.2520 & 0.2669 \\
\hline Exact & 0.4679 & 0.3474 & & & & \\
\hline Chen Quasi-Exact & 0.4679 & 0.3474 & & & & \\
\hline Bootstrap & 0.4679 & 0.3474 & 0.1205 & -0.0133 & 0.2571 & 0.2704 \\
\hline
\end{tabular}

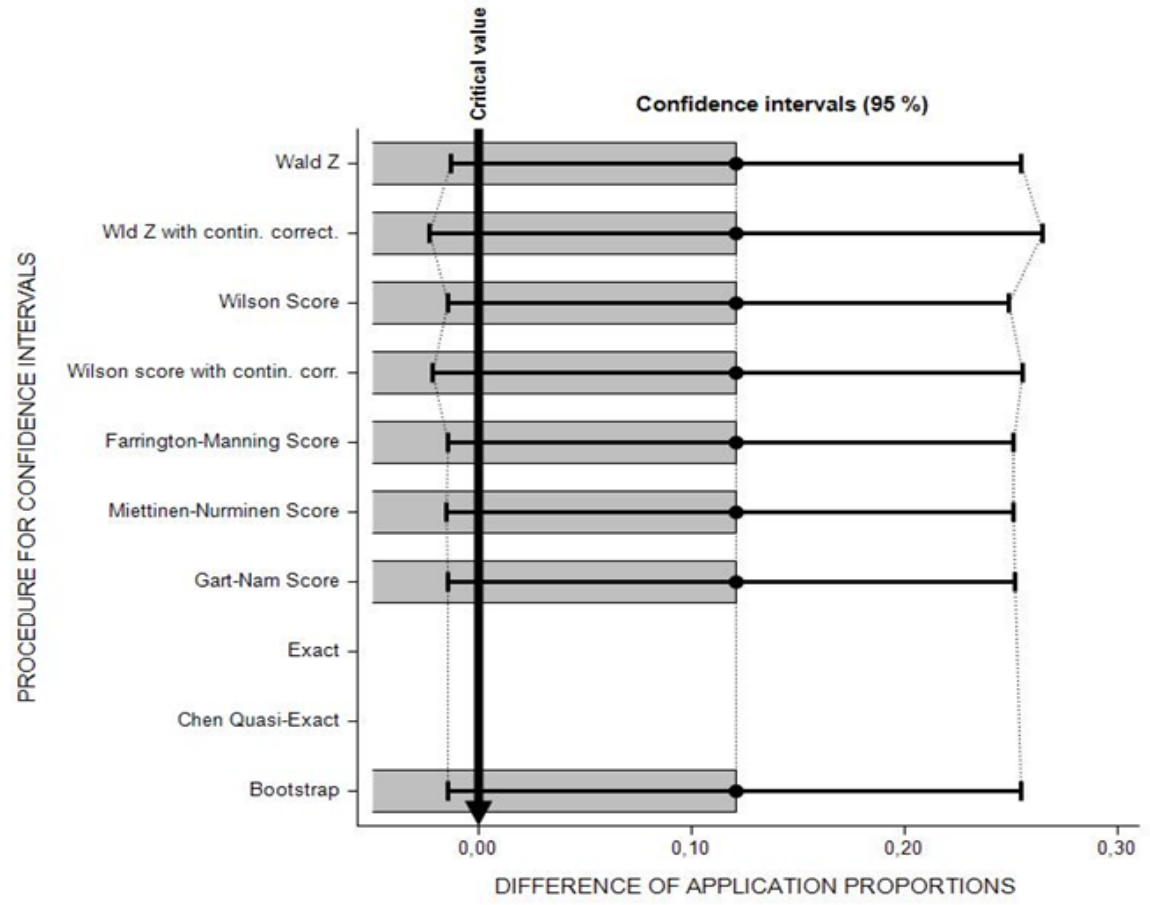

Figure-2. Unpair test for the $2 \times 2$ table - Difference of proportions - Confidence intervals [Basic analysis].

Since the observed probability value is greater than the statistical significance level applied in the test $(\alpha=0.05$ $=5 \%$, we cannot reject the null hypothesis $\left(\mathrm{H}_{0}\right)$ and we must state that the difference between the 2010 application proportion and the 2008 application proportion is equal to 1. This means that the test regarding the proportion difference as a ratio (obtained by mutually dividing the proportions, i.e., $\mathrm{P}_{2010} / \mathrm{P}_{2008}$ ) did not detect any statistically significant difference between application of strategic pricing policy in 2008 versus 2010 (i.e., across the period of the 2008-2009 economic crisis).

\subsection{Confidence Intervals}

All the procedures which were carried out are detailed in Table 6 and Figure 3, and they indicate that the value of the year-on-year proportion ratio $\left(\mathrm{P}_{2010} / \mathrm{P}_{2008}\right)$ is in the interval of 1.3408 to 1.3470 . For example, the asymptotic Miettinen-Nurminen procedure for confidence intervals shows that the proportion ratio equals 1.3470 and is in the interval of 0.9638 to 1.9076 with a $95 \%$ probability, i.e., in the interval with the width of 0.9438 . This means that - assuming the given statistical significance level $(\alpha=0.05=5 \%)$ - the procedure regarding the 
proportion difference as a ratio (obtained by mutually dividing the proportions, i.e., $\mathrm{P}_{2010} / \mathrm{P}_{2008}$ ) did not detect any statistically significant difference between application of strategic pricing policy in 2008 versus 2010 (i.e., across the period of the 2008-2009 economic crisis), which supports the results obtained by the tests specified in the section above.

Table-5. Unpair test for the 2x2 table - Ratio of proportions [Basic analysis]

\begin{tabular}{|c|c|c|c|c|c|c|}
\hline \multirow[t]{2}{*}{ TEST } & \multicolumn{2}{|c|}{$\begin{array}{l}\text { Application } \\
\text { proportion }\end{array}$} & \multirow[t]{2}{*}{$\mathbf{P}_{2010} / \mathbf{P}_{2008}$} & \multirow[t]{2}{*}{$\begin{array}{c}\text { Test } \\
\text { statistics }\end{array}$} & \multirow[t]{2}{*}{$\begin{array}{c}\text { Observed probability } \\
\text { (p-value) }\end{array}$} & \multirow[t]{2}{*}{$\begin{array}{c}\text { Reject } H_{0} \text { at } \\
\alpha=0.05 ?\end{array}$} \\
\hline & $\mathbf{P}_{2010}$ & $\mathbf{P}_{2008}$ & & & & \\
\hline Wald Z & 0.4679 & 0.3474 & 1.3470 & 1.745 & 0.0810 & No \\
\hline $\begin{array}{c}\text { Barnard's } \\
\text { Exact }\end{array}$ & 0.4679 & 0.3474 & 1.3470 & & & \\
\hline
\end{tabular}

Table-6. Unpair test for the $2 \times 2$ table - Ratio of proportions - Confidence intervals [Basic analysis].

\begin{tabular}{|c|c|c|c|c|c|c|}
\hline \multirow[t]{2}{*}{ Procedure } & \multicolumn{2}{|c|}{$\begin{array}{l}\text { Application } \\
\text { proportion }\end{array}$} & \multirow[t]{2}{*}{$\mathbf{P}_{2010} / \mathbf{P}_{2008}$} & \multicolumn{3}{|c|}{$\begin{array}{l}\text { Confidence intervals }(95 \%) \text { for } P_{2010} \\
\qquad / P_{2008}\end{array}$} \\
\hline & $\mathbf{P}_{2010}$ & $\mathbf{P}_{2008}$ & & $\begin{array}{c}\text { Lower } \\
\text { limit }\end{array}$ & $\begin{array}{l}\text { Upper } \\
\text { limit }\end{array}$ & Width \\
\hline $\begin{array}{l}\text { Farrington-Manning } \\
\text { Score }\end{array}$ & 0.4679 & 0.3474 & 1.3470 & 0.9646 & 1.9060 & 0.9414 \\
\hline $\begin{array}{l}\text { Miettinen-Nurminen } \\
\text { Score }\end{array}$ & 0.4679 & 0.3474 & 1.3470 & 0.9638 & 1.9076 & 0.9438 \\
\hline Gart-Nam Score & 0.4679 & 0.3474 & 1.3470 & 0.9646 & 1.9179 & 0.9533 \\
\hline Katz Logarithm & 0.4679 & 0.3474 & 1.3470 & 0.9581 & 1.8937 & 0.9356 \\
\hline Walter Logarithm $+1 / 2$ & 0.4679 & 0.3474 & 1.3408 & 0.9566 & 1.8791 & 0.9225 \\
\hline Fleiss & 0.4679 & 0.3474 & 1.3470 & 0.9418 & 1.9484 & 1.0067 \\
\hline Exact & 0.4679 & 0.3474 & & & & \\
\hline Chen Quasi-Exact & 0.4679 & 0.3474 & & & & \\
\hline Bootstrap & 0.4679 & 0.3474 & 1.3470 & 0.9388 & 1.8880 & 0.9492 \\
\hline
\end{tabular}

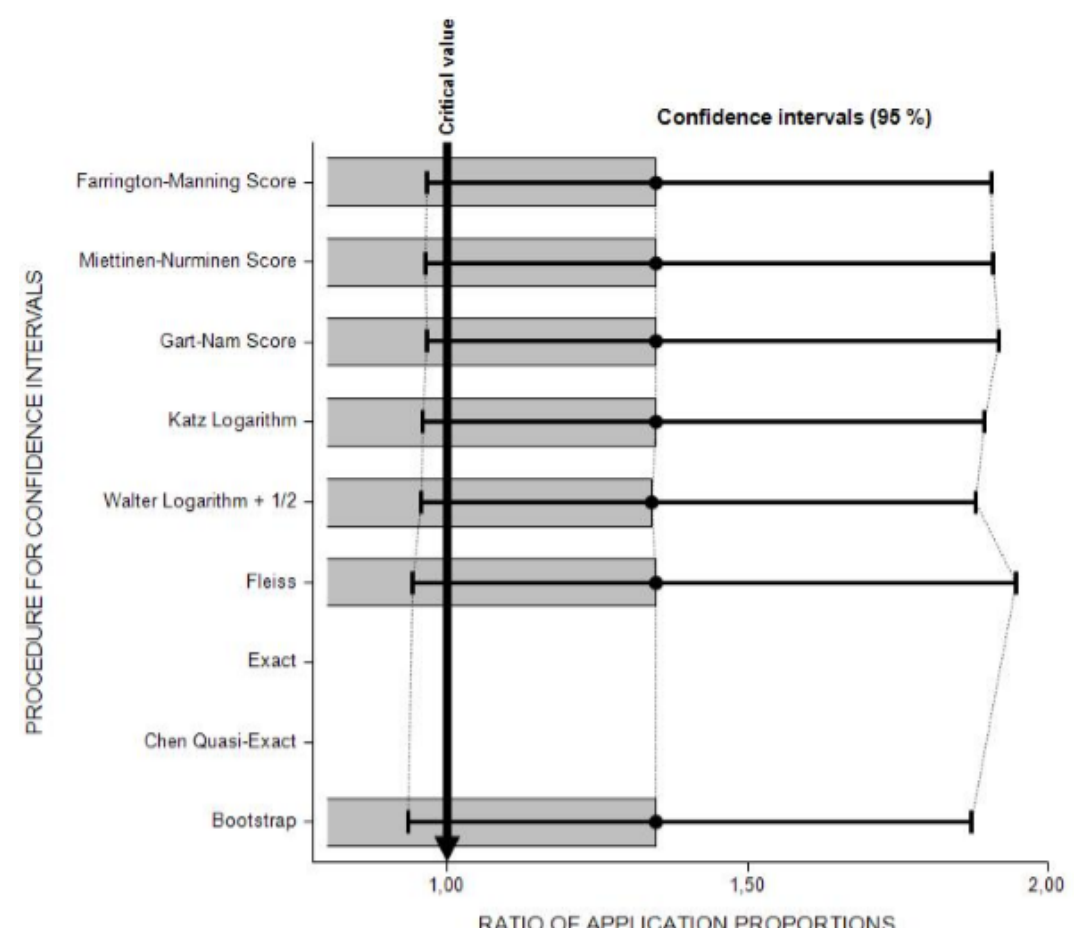

Figure-3. Unpair test for the $2 \times 2$ table - Ratio of proportions - Confidence intervals [Basic analysis]. 
5.2.3.3. Odds ratio of Proportions $\left(\mathrm{O}_{2010} / \mathrm{O}_{2008}\right)$

5.2.3.3.1. Test

We tested the null hypothesis, which assumes that the odds ratio of the 2010 application proportion and the 2008 application proportion equals 1 versus the alternative hypothesis assuming the opposite, i.e.:

$\mathrm{H}_{0}: \mathrm{O}_{2010} / \mathrm{O}_{2008}=1$ vs. $\mathrm{H}_{\mathrm{a}}: \mathrm{O}_{2010} / \mathrm{O}_{2008} \neq 1$

All the tests which were performed are detailed in Table 7, and the results indicate that the probability of the null hypothesis being true is in the interval of 0.0819 to 0.1087. For example, the asymptotic Odds Ratio Logarithm test returns a statistic of 1.740 and a observed probability value (p-value) of 0.0819 . Since the observed probability value is greater than the statistical significance level applied in the test ( $\alpha=0.05=5 \%$ ), we cannot reject the null hypothesis $\left(\mathrm{H}_{0}\right)$ and we must state that the difference between the 2010 application proportion and the 2008 application proportion is equal to 1 . This means that the test regarding the proportion difference as an odds ratio (obtained by mutually dividing the odds, i.e., $\mathrm{O}_{2010} / \mathrm{O}_{2008}$ ) did not detect any statistically significant difference between the application of strategic pricing policy in 2008 versus 2010 (i.e., across the period of the 2008-2009 economic crisis).

Table-7. Unpair test for the $2 \times 2$ table - Odds ratio of proportions [Basic analysis].

\begin{tabular}{l|c|c|c|c|c|c}
\hline \multirow{2}{*}{ TEST } & \multicolumn{2}{|c|}{$\begin{array}{c}\text { Application } \\
\text { proportion }\end{array}$} & $\mathbf{O}_{2010} / \mathbf{O}_{\text {soos }}$ & $\begin{array}{c}\text { Test } \\
\text { statistics }\end{array}$ & $\begin{array}{c}\text { Observed } \\
\text { probability (p- } \\
\text { value) }\end{array}$ & $\begin{array}{c}\text { Reject } \mathbf{H}_{0} \text { at } \\
\boldsymbol{\alpha}=\mathbf{0 . 0 5} ?\end{array}$ \\
\cline { 2 - 6 } & $\mathbf{P}_{2010}$ & $\mathbf{P}_{\text {2008 }}$ & & & 0.0819 & No \\
\hline Odds Ratio Logarithm & 0.4679 & 0.3474 & 1.6520 & 1.740 & 0.0819 & No \\
\hline Mantel-Haenszel & 0.4679 & 0.3474 & 1.6520 & 1.740 & 0.1087 & No \\
\hline Exact & 0.4679 & 0.3474 & 1.6520 & 51.000 & 000 \\
\hline
\end{tabular}

\subsection{Confidence Intervals}

All the procedures performed are detailed in Table 8 and Figure 4, and the results indicate that the value of the year-on-year proportion odds ratio $\left(\mathrm{O}_{2010} / \mathrm{O}_{2008}\right)$ is in the interval of 1.6424 to 1.6520. For example, the asymptotic Miettinen-Nurminen procedure for confidence intervals shows that the proportion odds ratio equals 1.6520 and is in the interval of 0.9391 to 2.9060 with a $95 \%$ probability, i.e., in the interval with the width of 1.9669 . This means that - assuming the given statistical significance level $(\alpha=0.05=5 \%)$ - the procedure regarding the proportion difference as an odds ratio (obtained by mutually dividing the proportions, i.e., $\mathrm{O}_{2010} / \mathrm{O}_{2008}$ ) did not detect any statistically significant difference between application of strategic pricing policy in 2008 versus 2010 (i.e., across the period of the 2008-2009 economic crisis), which supports the results obtained by the tests specified in the section above.

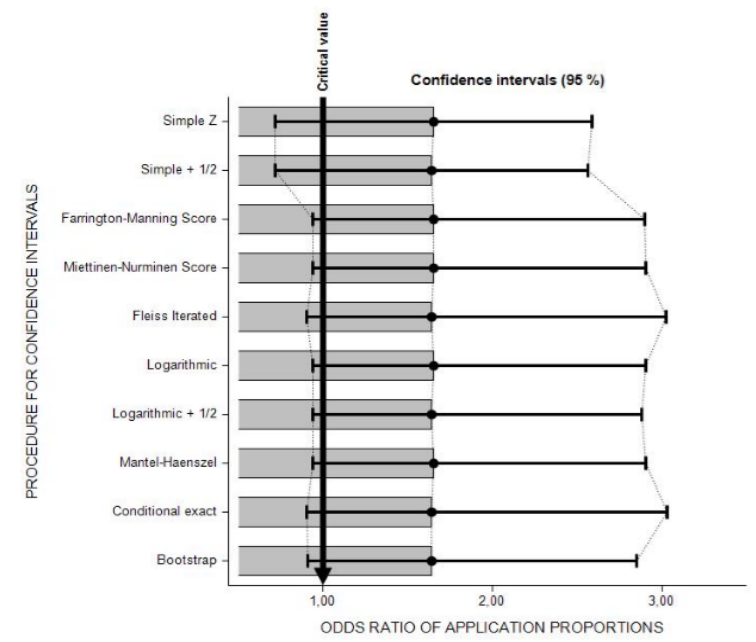

Figure-4. Unpair test for the $2 \mathrm{x} 2$ table - Odds ratio of proportions - Confidence intervals [Basic analysis]. 
Table-8. Unpair test for the $2 \times 2$ table - Odds ratio of proportions - Confidence intervals [Basic analysis].

\begin{tabular}{|c|c|c|c|c|c|c|}
\hline \multirow[t]{2}{*}{ Procedure } & \multicolumn{2}{|c|}{$\begin{array}{l}\text { Application } \\
\text { proportion }\end{array}$} & \multirow[t]{2}{*}{$\mathbf{O}_{2010} / \mathbf{O}_{2008}$} & \multicolumn{3}{|c|}{$\begin{array}{l}\text { Confidence intervals }(95 \%) \text { for } \mathbf{O}_{2010} / \\
\mathbf{O}_{2008}\end{array}$} \\
\hline & $\mathbf{P}_{2010}$ & $\mathbf{P}_{2008}$ & & $\begin{array}{l}\text { Lower } \\
\text { limit }\end{array}$ & $\begin{array}{l}\text { Upper } \\
\text { limit }\end{array}$ & Width \\
\hline Simple Z & 0.4679 & 0.3474 & 1.6520 & 0.7176 & 2.5865 & 1.8688 \\
\hline Simple $+1 / 2$ & 0.4679 & 0.3474 & 1.6424 & 0.7186 & 2.5663 & 1.8477 \\
\hline Farrington-Manning Score & 0.4679 & 0.3474 & 1.6520 & 0.9403 & 2.9020 & 1.9616 \\
\hline Miettinen-Nurminen Score & 0.4679 & 0.3474 & 1.6520 & 0.9391 & 2.9060 & 1.9669 \\
\hline Fleiss Iterated & 0.4679 & 0.3474 & 1.6424 & 0.9029 & 3.0285 & 2.1257 \\
\hline Logarithmic & 0.4679 & 0.3474 & 1.6520 & 0.9384 & 2.9085 & 1.9701 \\
\hline Logarithmic $+1 / 2$ & 0.4679 & 0.3474 & 1.6424 & 0.9358 & 2.8825 & 1.9467 \\
\hline Mantel-Haenszel & 0.4679 & 0.3474 & 1.6520 & 0.9384 & 2.9085 & 1.9701 \\
\hline Conditional Exact & 0.4679 & 0.3474 & 1.6424 & 0.9039 & 3.0297 & 2.1258 \\
\hline Bootstrap & 0.4679 & 0.3474 & 1.6424 & 0.9091 & 2.8835 & 1.9745 \\
\hline
\end{tabular}

\subsubsection{Analysis Summary (Unpaired Test for 2x2 Table)}

All three variants of the unpaired test for the $2 \times 2$ table returned the same outcome: there is no statistically significant difference between the 2010 application proportion and the 2008 application proportion. Since the above result was obtained by employing several methodically different statistical instruments (the principle of statistical multi-instrumentality), all of which produced the same outcome, we can state that this conclusion has a very high level of reliability.

\section{DISCUSSION AND CONCLUSIONS}

Regarding 2008, the information required was provided by $75.40 \%$ of the total count of logistics service providers contacted, which is considerably high. The percentage of providers who supplied the information for 2010 even increased to $86.51 \%$. There are two conclusions to be derived from this data. First, the respondent information obtained in the research is of a high quality. Thus, the assumption that collecting the information required by means of telephone inquiry (instead of a questionnaire survey) as a reliable data collection method has been verified; this has also been confirmed by Musselwhite, Cuff, McGregor, \& King (2007). Second, the number of providers who provided information for 2010 was higher than that for 2008. This outcome could be reasonably expected considering the fact that 2010 is more recent, so it is more likely that the information required will be available and accessible (Herman, 1977).

As the core of the analysis, we examined the assumption that economic instability may have an influence on the application of strategic pricing policy by logistics service providers. For this purpose, we formulated the hypothesis based on the assumption that the proportion of the providers applying the strategic pricing policy shortly after the culmination of the 2008-2009 economic crisis (2010) (46.79\% based on the data obtained from the respondents) is higher than the number of the providers shortly before the crisis onset (2008) (34.74\%). In accordance with the principle of statistical multi-instrumentality, a wide range of statistical instruments was employed, each of which examined the difference between the year-on-year proportions from a specific, mutually different aspect. In addition, several statistical instruments (tests and procedures) were used to verify a single hypothesis. All of the statistical instruments applied produced the same outcome: on the standard level of statistical significance $(\alpha=0.05=5 \%)$, there is no difference between the compared application proportions, which means that - from the viewpoint of exact statistics - the number of the logistics service providers applying the strategic pricing policy did not change across the duration of the 2008-2009 economic crisis. Thus, there is no reason to suppose that evidence exists indicating that macroeconomic instability could have an influence on whether, and to what extent, providers apply strategic pricing in their marketing practices. This means that - according to the research - the crisis did not "compel" the logistics providers to re-assess their pricing policy to better accommodate the new conditions of the 
intensified market environment. This discovery is highly surprising and quite incompatible with the original research assumption that, under market pressure, firms have no choice other than to resort to reducing their prices in order to ensure their economic survival in a turbulent environment, as also assumed by Rowe \& Clark (1927).

We can only speculate about the causes of this outcome. They may consist of several factors. One may be the fact that the providers of logistics services did not reduce their prices, but only suspended their growth, thereby inducing a state of price stagnation, as advocated by Ping (2009). Another factor may be price rigidity (or low price flexibility), which is typically manifested in the case of "downward" price pressure, i.e., a tendency of the price to decrease, whereas in the opposite direction, the price is typically more flexible. Another possible explanation may be the fact that the effect of Covid-19 and the related measures on the demand for logistics services was/is ambiguous. On the one hand, the measures brought in to reduce the spread of the virus worsened the economic situations of the firms, i.e., potential clients of logistics service providers declined, which consequently led to a lower demand for logistics services, thereby decreasing the price clients are willing to pay for these services. However, on the other hand, the coronavirus measures may also contribute to an increase in demand for logistics services because these measures inevitably bring about considerable restrictions of personal transport. Thus, it is questionable which of the two factors prevails. If the former is predominant, then economic crisis should induce pressure on price reduction. If the latter factor is prevailing, the demand for logistics services should not only remain the same as in the pre-crisis period, but should even be higher, thereby increasing the market price of logistics services.

Further discussion on the factor(s) leading to the conclusions obtained in this research is out of the scope of this paper because there is a lack of base data for this. Therefore, there is scope for further research with the aim of overcoming the limitations of this research, which may possibly have caused its failure to detect the influence of the economic crisis on the application of strategic pricing policy by logistics service providers. One of the prospective research possibilities consists of a more sensitive detection of differences in the application of strategic pricing policy by increasing the number of alternatives of its application, i.e., introducing an additional alternative of a "partial" application, as proposed by Gummesson \& Polese (2009). This enhancement is expected to enable detection of less remarkable nuances of the situation, making it possible to detect eventual differences and small shifts in the examined field where this research - based on two application alternatives only - failed. As the first and crucial step, however, this would require a precise definition of the term "partial application" of the strategic pricing policy, which may be a considerable problem. One of the possible definitions of "partial application" could be a situation where the strategic pricing policy is being discussed and/or is in the process of being implemented. Another alternative could be a situation where the strategic pricing policy has been applied but only for some (selected) customers of the logistics service provider. Also, an enhanced analysis design would require employment of a different set of statistical instruments, in this case, for comparing two trinomial proportions.

Another method of overcoming the limitations of this research and following a new direction for further research can consist of detecting eventual long-term trends in the application of strategic pricing policy. In such a case, the analysis would cover not only the years 2008 and 2010 but would extend its coverage to the further years following the crisis culmination. The reason for the time extension of the research is the assumption that the changes in the pricing policy of the logistics providers can occur not only in a period during the crisis or shortly after its culmination, but in a longer time period, as supported by Magdum (2019). This means that logistics providers may only apply the strategic pricing policy after a considerable time delay of several years following the crisis. This delay may have its source in the price rigidity, as mentioned above, which may be caused by the rigidity of internal organization processes (especially in case of large companies) or by the fact that the incentives for the application of strategic pricing policy may require some time to become apparent. This is because - first of all - the providers of logistics services must "feel" the changed, more competitive market environment inducing market pressure on price reduction and they realize the necessity to implement the measures and adapt to the new market conditions. Provided the number of application alternatives remained two (No vs. Yes), the analysis design would 
require statistical instruments to compare multiple binomial proportions (we would compare several proportions, whose number corresponds with the number of the compared years).

Although this research failed to detect a statistically difference between the application of strategic pricing policy across two periods, the authors believe that it may still present a valuable contribution to understanding the influence of the macroeconomic environment on microeconomic behavior of the firms with regards to their marketing strategies.

Funding: This study received no specific financial support.

Competing Interests: The authors declare that they have no competing interests.

Acknowledgement: All authors contributed equally to the conception and design of the study.

\section{REFERENCES}

Ahsan, S., \& Larry, S. (1988). Microeconomic theory. The Canadian Journal of Economics, 21(2), 436-452.

Amin, A., \& Thrift, N. (1992). Neo-Marshallian nodes in global networks. International Journal of Urban and Regional Research, 16(4), 571-587. Available at: https://doi.org/10.1111/j.1468-2427.1992.tbo0197.x.

Baumol, W. J., Cyert, R. M., \& March, J. G. (1964). A behavioral theory of the firm. Journal of Marketing Research, 1(1), 74-91.

Coase, R. (2012). The nature of the firm. In: Randall S. Kroszner and Louis Putterman, eds. The economic nature of the firm (pp. 79-95). Cambridge: Cambridge University Press.

Conner, K. R., \& Prahalad, C. K. (1996). A resource-based theory of the firm: Knowledge versus opportunism. Organization Science, 7(5), 477-501. Available at: https://doi.org/10.1287/orsc.7.5.477.

Cosgrove, J. D., Pettis, C. D., \& Mullett, C. E. (1979). U.S. Patent No. 4,180,709. Washington, DC: U.S. Patent and Trademark Office.

Eichner, A. S. (1987). Prices and pricing. Journal of Economic Issues, 21(4), 1555-1584.

Gourinchas, P.-O. (2020). Flattening the pandemic and recession curves. Mitigating the COVID Economic Crisis: Act Fast and Do Whatever, 31(2), 57-62.

Gummesson, E., \& Polese, F. (2009). B2B is not an island! Journal of Business \&̊ Industrial Marketing, 24(5/6)), 337-350.

Harrison, J. S., \& Wicks, A. C. (2013). Stakeholder theory, value, and firm performance. Business Ethics Quarterly, 23(1), 97-124. Available at: https://doi.org/10.5840/beq20132314.

Herman, J. B. (1977). Mixed-mode data collection: Telephone and personal interviewing. Journal of Applied Psychology, 62(4), 399-404. Available at: https://doi.org/10.1037/002 1-9010.62.4.399.

Järvinen, J., \& Taiminen, H. (2016). Harnessing marketing automation for B2B content marketing. Industrial Marketing Management, 54, 164-175. Available at: https://doi.org/10.1016/j.indmarman.2015.07.002.

Kjeldgaard, D., \& Askegaard, S. (2006). The glocalization of youth culture: The global youth segment as structures of common difference. Journal of Consumer Research, 33(2), 231-247. Available at: https://doi.org/10.1086/506304.

Klaas, B. S., McClendon, J., \& Gainey, T. W. (1999). HR outsourcing and its impact: The role of transaction costs. Personnel Psychology, 52(1), 113-136. Available at: https://doi.org/10.1111/j.1744-6570.1999.tbo1816.x.

Magdum, M. A. R. (2019). E-commerce users in India. International Journal of Trend in Scientific Research and Development, 9(1), 17-20. Available at: https://doi.org/10.31142/ijtsrd23052.

Musselwhite, K., Cuff, L., McGregor, L., \& King, K. M. (2007). The telephone interview is an effective method of data collection in clinical nursing research: A discussion paper. International Journal of Nursing Studies, 44(6), 1064-1070.

Naidoo, V. (2010). Firm survival through a crisis: The influence of market orientation, marketing innovation and business strategy. Industrial Marketing Management, 39(8), 1311-1320. Available at: https://doi.org/10.1016/j.indmarman.2010.02.005.

Pause, D., Holtkemper, D., Kraut, A., Marek, S., Janßen, J., Linnartz, M., \& Schmitz, S. (2020). Supply-chain-management 4.0. Zeitschrift Für Wirtschaftlichen Fabrikbetrieb, 115(5), 318-320. 
Ping, L. (2009). Strategy of green logistics and sustainable development. Paper presented at the In 2009 International Conference on Information Management, Innovation Management and Industrial Engineering. IEEE.

Rowe, J. W. F., \& Clark, F. E. (1927). Principles of marketing. Economica, 19(1), 118-119.

Vijay, R. (2000). Development microeconomics. Artha Vijnana: Journal of The Gokhale Institute of Politics and Economics, 42(4), 385402 .

Views and opinions expressed in this article are the views and opinions of the author(s), Asian Economic and Financial Review shall not be responsible or answerable for any loss, damage or liability etc. caused in relation to/arising out of the use of the content. 